\title{
VERMICOMPOST APPLICATION IMPROVING SEMIARID-GROWN CORN GREEN EAR AND GRAIN YIELDS ${ }^{1}$
}

\author{
PAULO SÉRGIO LIMA E SILVA²*, PAULO IGOR BARBOSA E SILVA², VIANNEY REINALDO DE OLIVEIRA², \\ FÁBIO HENRIQUE TAVARES DE OLIVEIRA ${ }^{3}$, LUCAS RAMOS DA COSTA ${ }^{2}$
}

\begin{abstract}
Intensive corn farming quickly depletes soil organic matter in the nutrient-poor soils of the Brazilian semiarid region. Application of vermicompost, an excellent organic fertilizer, could help solve that problem. This study evaluated the effect of applying Eisenia fetida vermicompost in the seeding furrows, at 0 , 2, 4, 6, 8, and $10 \mathrm{Mg} \mathrm{ha}^{-1}$ application rates, on the green ear yield and grain yield of two corn cultivars. Treatments were replicated five times with split-plots (vermicompost application rates within plots) in a completely randomized block design. The number of mature ears, number of kernels per ear (cultivar BR 106), and 100-kernel weight (cultivar AG 1051) were not affected by vermicompost application rate. However, vermicompost application increased total number and weight of unhusked and husked marketable green ears as well as grain yield. Total number of green ears was higher in cultivar BR 106 than in cultivar AG 1051. Conversely, grain yield and total ear weight and marketable weight of unhusked and husked green ears was higher in cultivar AG 1051, but responses in the latter two traits were dose-dependent.
\end{abstract}

Key words: Humus. Earthworm. Zea mays. Eisenia fetida. Cultivars.

\section{APLICAÇÃO DE VERMICOMPOSTO ELEVA OS RENDIMENTOS DE ESPIGAS VERDES E DE GRÃOS DE MILHO NO SEMIÁRIDO}

RESUMO - A exploração intensiva do milho reduz rapidamente os já considerados baixos teores de matéria orgânica dos solos do semiárido brasileiro. A aplicação de vermicompostos, considerados excelentes adubos orgânicos, poderia contribuir para a solução desse problema. O objetivo do presente trabalho foi avaliar os efeitos da aplicação, nos sulcos de semeadura, de doses $\left(0,2,4,6,8\right.$ e $\left.10 \mathrm{Mg} \mathrm{ha}^{-1}\right)$ de vermicomposto de Eisenia fetida, obtido a partir de esterco bovino, sobre os rendimentos de espigas verdes e de grãos de cultivares de milho (AG 1051 e BR 106). Utilizou-se o delineamento de blocos ao acaso com cinco repetições e parcelas subdivididas (vermicomposto nas parcelas). A aplicação de doses de vermicomposto não influenciou o número de espigas maduras, número de grãos espiga ${ }^{-1}$ (na cultivar BR 106) e massa de 100 grãos (na cultivar AG 1051). Mas a aplicação do vermicomposto aumentou os números e as massas de espigas verdes, totais e comercializáveis, empalhadas e despalhadas, e o rendimento de grãos. A cultivar BR 106 foi superior à cultivar AG 1051 quanto ao número total de espigas verdes. O inverso ocorreu nas massas total e de espigas verdes comercializáveis, empalhadas e despalhadas, e no rendimento de grãos. Mas nessas duas últimas características a superioridade da cultivar AG 1051, dependeu da dose do adubo.

Palavras-chave: Húmus. Minhoca. Zea mays. Eisenia fetida. Cultivares.

\footnotetext{
*Corresponding author

${ }^{1}$ Received for publication in $02 / 11 / 2015$; accepted in $10 / 18 / 2016$

${ }^{2}$ Department of Plant Science, Universidade Federal Rural do Semi-Árido, Mossoró, RN, Brazil; paulosergio@ufersa.edu.br, pauloigorbs@gmail.com, vianney.reinaldo@hotmail.com, lucas ramosjp@hotmail.com.

${ }^{3}$ Department of Environmental and Technological Sciences, Universidade Federal Rural do Semi-Árido, Mossoró, RN, Brazil; fabio@ufersa.edu.br.
} 


\section{INTRODUCTION}

Soils in the Brazilian semiarid region usually have low organic matter content, an important soil quality indicator (MANLAY; FELLER; SWIFT, 2007). Corn crops, grown intensively and under irrigation in the region (often producing up to three harvests per year), tend to quickly deplete organic matter content. In addition, in both irrigated and dryland corn, virtually all plant biomass aboveground is removed to feed cattle after the ears are harvested. Together with the high temperatures in the region, this results in intense mineralization of soil organic matter and crop residues occurs, resulting in decreased soil quality (MARIN et al., 2006; DINESH et al., 2010). Organic fertilizers and/or crop residues, used either alone or in combination with mineral fertilizers, could help minimize these issues (MANLAY; FELLER; SWIFT, 2007).

Vermicomposts - the end-product of the breakdown of organic matter by earthworms (ALVAREZ et al., 2004) - are finely divided materials with high porosity, aeration, drainage, water-holding capacity and microbial activity, stabilized by interactions between earthworms and microorganisms in a non-thermophilic process (ARANCON et al., 2004a). Vermicomposts release nutrients in plant-available forms after mineralization in the soil, and have large particulate surface areas that provide sites for microbial (fungi, bacteria, and actinomycetes) activity and nutrient retention, improving crop growth and yield (ARANCON; GALVIS; EDWARDS, 2005). In recent years, a large number of studies investigated the effects of vermicompost application on crops such as rice, sorghum, and corn (PATIL; SHEELAVANTAR, 2006; SUJATHA et al., 2008; BRITO et al., 2009; LAZCANO et al., 2011; TEJADA; BENITEZ, 2011), likely due to a growing worldwide concern for the sustainability of agricultural systems (GUTIÉRREZ-MICELI et al., 2008). In general, these studies have found positive effects of vermicompost application on crop yields.

The objective of this study was to evaluate the effect of a range of vermicompost application rates on green ear yield and grain yield for two corn cultivars grown under irrigation in the Brazilian semi-arid region.

\section{MATERIAL AND METHODS}

The study was conducted from August to November 2009 at Rafael Fernandes Experimental Farm, Universidade Federal Rural do Semi-Arido (UFERSA), located $20 \mathrm{~km}$ from Mossoró, RN, Brazil ( $5^{\circ} 11^{\prime} \mathrm{S}$ and $37^{\circ} 20^{\prime} \mathrm{W}, 18 \mathrm{~m}$ elevation). Climate information for the region was summarized by Carmo Filho and Oliveira (1989).

The experiment was sprinkler-irrigated. The depth of water required by corn $(5.6 \mathrm{~mm})$ was calculated based on the actual depth of the root system $(0.4 \mathrm{~m})$. Irrigation duration was based on the water retained by the soil at a tension of $0.04 \mathrm{Mpa}$. A one-day irrigation schedule was established. Irrigation was started after seeding and was suspended one day before each harvest. The soil in the area is Arenic Hapludult (red yellow argisol or PVA) (EMBRAPA, 2006). Soil analysis results for the study area are presented in Table 1 .

The soil was tilled by two harrowing operations. Before seeding, $30 \mathrm{~kg} \cdot \mathrm{ha}^{-1} \mathrm{~N}$ (ammonium sulfate), $60 \mathrm{~kg} \cdot \mathrm{ha}^{-1} \mathrm{P}_{2} \mathrm{O}_{5}$ ( single superphosphate), and $30 \mathrm{~kg} \cdot \mathrm{ha}^{-1} \mathrm{~K}_{2} \mathrm{O}$ (potassium chloride) were applied as base fertilizers. The fertilizers were applied by hand in furrows at a depth of approximately $20 \mathrm{~cm}$. The furrows were ploughed deeper than usual to allow in-furrow application of fertilizers. Vermicompost, prepared using cattle manure mixed with Eisenia fetida (Savigny) worms, was applied by hand over the chemical fertilizers $(0,2,4,6,8$, and $\left.10 \mathrm{Mg} . \mathrm{ha}^{-1}\right)$ and the furrows were later covered with soil using a hoe. Fertilizers and vermicompost were applied in furrows, rather than by broadcasting, to reduce the amount of vermicompost used. The vermicompost analysis results (EMBRAPA, 1999) are presented in Table 1.

Hand seeding was performed on 07/29/2009 at $1.0 \mathrm{~m} \times 0.4 \mathrm{~m}$ spacing with four seeds/pit at an approximate depth of $5.0 \mathrm{~cm}$ in pits opened at the furrow walls. Thinning was performed 20 days after seeding (DAS), leaving the two more vigorous plants in each pit, resulting in a density equivalent to 50,000 plants $\mathrm{ha}^{-1}$ in the experimental stand. Two corn cultivars were evaluated: BR 106 and AG 1051. BR 106 is a free-pollination, medium-cycle, medium-sized, flint type, reddish-yellow variety. Corn cultivar AG 1051 is a short-sized, super-early double hybrid with yellow dent grain.

Pest control was done by spraying deltamethrin $\left(250 \mathrm{~mL} \cdot \mathrm{ha}^{-1}\right)$ at seven and 14 DAS. Weeds were removed with a hoe 20 and 45 DAS. After each weeding, the stand was fertilized with $30 \mathrm{~kg} \cdot \mathrm{ha}^{-1} \mathrm{~N}$ (ammonium sulfate). 
P. S. L. SILVA et al.

Table 1. Chemical analysis results for the soil and vermicompost utilized in the experiment ${ }^{1}$.

\begin{tabular}{lccc}
\hline Attributes & Units & Soil analysis & Vermicompost analysis \\
\hline Organic matter & $\mathrm{g} \mathrm{kg}^{-1}$ & 0.76 & 10.50 \\
$\mathrm{pH}$ & - & 6.5 & - \\
$\mathrm{C}$ & $\%$ & 0.44 & 6.31 \\
$\mathrm{P}$ & $\mathrm{mg} \mathrm{dm}$ & 3.22 & 38.41 \\
$\mathrm{Na}^{+}$ & $\mathrm{cmol}_{\mathrm{c}} \mathrm{dm}^{-3}$ & 1.00 & 5.90 \\
$\mathrm{~K}^{+}$ & $\mathrm{cmol}_{\mathrm{c} \mathrm{dm}^{-3}}$ & 0.11 & 61.25 \\
$\mathrm{Ca}^{2+}$ & $\mathrm{cmol}_{\mathrm{c} \mathrm{dm}^{-3}}$ & 0.07 & 71.66 \\
$\mathrm{Mg}^{2+}$ & $\mathrm{cmol}_{\mathrm{c} \mathrm{dm}^{-3}}$ & 1.20 & 0.66 \\
$\mathrm{Al}^{3+}$ & $\mathrm{cmol}_{\mathrm{c} \mathrm{dm}^{-3}}$ & 0.72 & 1.28 \\
$\mathrm{H}+\mathrm{Al}$ & $\mathrm{cmol}_{\mathrm{c} \mathrm{dm}^{-3}}$ & 0.00 & 0.72 \\
$\mathrm{SB}$ & $\mathrm{cmol}_{\mathrm{c} \mathrm{dm}^{-3}}$ & 0.74 & - \\
$\mathrm{CEC}$ & $\mathrm{cmol}_{\mathrm{c}} \mathrm{dm}^{-3}$ & 2.10 & - \\
$\mathrm{t}$ & $\mathrm{cmol}_{\mathrm{c} \mathrm{dm}^{-3}}$ & 2.84 & - \\
$\mathrm{m}$ & $\%$ & 2.10 & - \\
$\mathrm{V}$ & $\%$ & 0.00 & - \\
\hline
\end{tabular}

${ }^{1}$ Analyses conducted according to EMBRAPA (1999).

Treatments were replicated five times with split-plots (vermicompost application rate within plots) in a complete randomized block design. Each experimental unit consisted of four $6.0 \mathrm{~m}$-long rows. The usable area was the two central rows, discarding plants from one pit at each end. One usable row was selected to evaluate green ear yield and the other was used to assess grain yield and its components.

Green ear harvesting was performed every two days (as the grain reached the "green corn" stage), during the period from 70 to 76 days after seeding. The total number and weight of unhusked green ears and the number and weight of marketable green ears, either unhusked or husked were evaluated. Unhusked marketable ears were $>22 \mathrm{~cm}$ in length, had good visual appearance, and were free of blemishes or holes from pests. Husked marketable ears were $>17 \mathrm{~cm}$ that displayed grain set and health suitable for commercialization.

Ripe ears were harvested 105 days after sowing, when the grain showed a water content of approximately $20 \%$. Next, the ears were husked and left to dry in the sun for approximately 72 hours, when they were threshed by hand. After weighing the grain, a $100 \mathrm{~g}$ sample was taken to estimate water content. Based on the water content thus determined, grain weight was corrected to a water content of $15.5 \%$. The number of kernels per ear was estimated based on 20 ears, and the 100-kernel weight was estimated based on five samples of 100 kernels.

The data were submitted to analysis of variance using SAEG-software developed by Universidade Federal de Viçosa (RIBEIRO JÚNIOR, 2001), while regression analyses were made with the software developed by Jandel (1992). The data were tested for homogeneity of variance prior to the analyses (BARTLETT, 1937). The regression models were selected based on the following criteria: biological explanation of the phenomenon, testing of model parameters by the Student's t test at 5\%, and model simplicity.

\section{RESULTS AND DISCUSSION}

Analysis of variance indicated an effect of cultivar $(\mathrm{C})$, vermicompost rate $(\mathrm{V})$, and the $\mathrm{C} \times \mathrm{V}$ interaction on the total number of green ears. Regression analysis indicated a positive effect on the total number of green ears as well as on the number of marketable ears, unhusked and husked (Table 2). Differences between the two types of analyzes are frequent (PIMENTEL-GOMES, 2009). Cultivar BR 106 was superior to cultivar AG 1051 with regard to total number of green ears (Table 2). As for the number of marketable husked green ears, cultivar AG 1051 was better than cultivar BR 106 at smaller doses of vermicompost, but the two cultivars did not differ at higher doses of fertilizer (Table 2).

With respect to total number of green ears in cultivars AG 1051 and BR 106, and number of marketable husked ears in cultivar BR 106, the positive effects of the application of vermicompost doses occurred up to certain rates $(7.37,5.79$, and

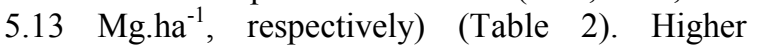
vermicompost rates resulted in yield reductions. However, with regard to number of marketable unhusked green ears in both cultivars and number of marketable husked ears in cultivar AG 1051, the maximum yields were obtained with the highest vermicompost rate (Table 2). Some authors (ARANCON et al., 2004a; SILVA et al., 2006) found no significant effects of vermicompost doses on some crop traits, similarly to this study. 
P. S. L. SILVA et al.

Table 2. Mean numbers of green ears of corn cultivars as a response to the application of vermicompost rates, obtained from cattle manure ${ }^{1}$.

\begin{tabular}{|c|c|c|c|c|c|c|c|c|c|}
\hline \multirow{4}{*}{$\begin{array}{l}\text { Vermicompost } \\
\text { rates } \\
\left(\mathrm{Mg} \mathrm{ha}^{-1}\right)(\mathrm{x})\end{array}$} & \multicolumn{9}{|c|}{ Number of ears ha ${ }^{-1}$} \\
\hline & \multicolumn{3}{|c|}{ Total } & \multicolumn{3}{|c|}{ Marketable unhusked } & \multicolumn{3}{|c|}{ Marketable husked } \\
\hline & \multicolumn{3}{|c|}{ Cultivars } & \multicolumn{3}{|c|}{ Cultivars } & \multicolumn{3}{|c|}{ Cultivars } \\
\hline & AG 1051 & BR 106 & Means & AG 1051 & BR 106 & Means & AG 1051 & BR 106 & Means \\
\hline 0 & 49039 & 47893 & 48466 & 44969 & 44635 & 44802 & $43046 \mathrm{a}$ & $35022 \mathrm{~b}$ & 39034 \\
\hline 2 & 49183 & 54964 & 52074 & 45195 & 49566 & 47381 & $40071 \mathrm{a}$ & $44370 \mathrm{a}$ & 42221 \\
\hline 4 & 50035 & 59452 & 54744 & 47498 & 48184 & 47841 & $45465 \mathrm{a}$ & $43553 \mathrm{a}$ & 44509 \\
\hline 6 & 50909 & 54486 & 52698 & 50909 & 49931 & 50420 & $49432 \mathrm{a}$ & $43950 \mathrm{~b}$ & 46691 \\
\hline 8 & 51631 & 53009 & 52320 & 48415 & 49936 & 49176 & $47646 \mathrm{a}$ & $42142 \mathrm{~b}$ & 44894 \\
\hline 10 & 50000 & 54869 & 52435 & 50000 & 51030 & 50515 & $47692 \mathrm{a}$ & $41720 \mathrm{~b}$ & 44706 \\
\hline Means & $50133 \mathrm{~b}$ & $54112 \mathrm{a}$ & - & $47831 \mathrm{a}$ & $48878 \mathrm{a}$ & 48355 & - & - & - \\
\hline \multicolumn{10}{|c|}{ Regression analysis for total number of green ears $(y)$} \\
\hline Cultivars & \multicolumn{5}{|c|}{ Equations $^{1}$} & \multicolumn{2}{|c|}{$\mathrm{x}$ for $\mathrm{y} \max$} & $\mathrm{y} \max$ & $R^{2}$ \\
\hline AG 1051 & \multicolumn{5}{|c|}{$\mathrm{y}=48814.0+138.3 \mathrm{x}^{2}-12.5 \mathrm{x}^{3}$} & \multicolumn{2}{|c|}{7.37} & 51319 & 0.94 \\
\hline BR 106 & \multicolumn{5}{|c|}{$y^{2}=2422110000+271291000 x-23439000 x^{2}$} & \multicolumn{2}{|c|}{5.79} & 56631 & 0.55 \\
\hline Mean & \multicolumn{5}{|c|}{$\mathrm{y}^{2}=2398770000+163344000 \mathrm{x}-13601000 \mathrm{x}^{2}$} & \multicolumn{2}{|c|}{6.00} & 53751 & 0.75 \\
\hline \multicolumn{10}{|c|}{ Regression analysis for number of marketable unhusked green ears $(\mathrm{y})$} \\
\hline Cultivars & \multicolumn{5}{|c|}{ Equações $^{1}$} & \multicolumn{2}{|c|}{$\mathrm{x}$ for $\mathrm{y} \max$} & $\mathrm{y} \max$ & $R^{2}$ \\
\hline AG 1051 & \multicolumn{5}{|c|}{$\mathrm{y}^{2}=2025670000+52295300 x$} & \multicolumn{2}{|c|}{10.00} & 50484 & 0.71 \\
\hline BR 106 & \multicolumn{5}{|c|}{$y=45296+1814 x^{0.5}$} & \multicolumn{2}{|c|}{10.00} & 51033 & 0.84 \\
\hline Mean & \multicolumn{5}{|c|}{$y=44813+1793 x^{0.5}$} & \multicolumn{2}{|c|}{10.00} & 50483 & 0.90 \\
\hline \multicolumn{10}{|c|}{ Regression analysis for number of marketable husked green ears (y) } \\
\hline Cultivars & \multicolumn{5}{|c|}{ Equations $^{1}$} & \multicolumn{2}{|c|}{$\mathrm{x}$ for $\mathrm{y} \max$} & $\mathrm{y} \max$ & $R^{2}$ \\
\hline AG 1051 & \multicolumn{5}{|c|}{$y^{2}=1737180000+664075 x$} & & 00 & 49003 & 0.59 \\
\hline BR 106 & $\mathrm{y}=35591$ & $112 x^{2}+5$ & $23 x^{0.5}$ & & & & 13 & 44465 & 0.90 \\
\hline Mean & $\mathrm{y}=38944$ & $-2034 x-1$ & $48 x^{2}$ & & & & 86 & 45917 & 0.96 \\
\hline CVplots, $\%$ & & 9.0 & & & 9.3 & & & 9.2 & \\
\hline CVsubplots, $\%$ & & 8.7 & & & 11.0 & & & 8.4 & \\
\hline
\end{tabular}

${ }^{1}$ For each trait, means followed by the same letter, in each row, do not differ from each other at 0.05 probability by Tukey's test. All parameters for all equations were significant at 0.05 probability by the $t$ test.

Regarding total ear weight and weight of marketable, unhusked and husked ears, effects of cultivars (C) and vermicompost rate (V) were observed, but the effects of the $\mathrm{C} \times \mathrm{V}$ interaction on those traits were not significant. Cultivar AG 1051 was superior to cultivar BR 106 for the three traits (Table 3). Vermicompost application increased total ear weight in cultivars AG 1051 and BR 106 up to

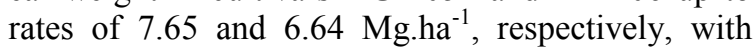
yield decreasing at higher rates (Table 3). Similarly, for marketable husked ear weight, the vermicompost doses that allowed maximum yield in both cultivars were 7.75 and $5.69 \mathrm{Mg} \mathrm{ha}^{-1}$, respectively. For marketable unhusked ear weight, maximum yields were obtained with the maximum vermicompost dose under study (Table 3).

Application of vermicompost rate (V), cultivar $(\mathrm{C})$, and the $\mathrm{V} \times \mathrm{C}$ interaction all affected grain yield. Cultivar AG 1051 did not differ from cultivar BR 106, in the three lower vermicompost rates applied, but was superior to the other cultivar for larger doses of fertilizer. Maximum grain yield values for cultivars AG 1051 and BR 106 were obtained with applications of 10.00 and
6.62 $\mathrm{Mg} \mathrm{ha}^{-1}$, respectively (Table 4). The observed increases in those yield values, as indicated by regression analysis, were due to increased numbers of kernels per ear in cultivar AG 1051 and kernel weight in cultivar BR 106, as the application of vermicompost did not influence the number of mature ears in any of the cultivars. For that trait, with an experimental mean of 50369 ears $\mathrm{ha}^{-1}$, the analysis of variance indicated coefficient of variation associated with plots $=2.0 \%$, and coefficient of variation associated with subplots $=2.2 \%$.

The discrepancies reported by different authors for the response to the application of vermicompost doses must be related to genotypic and environmental factors, as well as to vermicompost application rate. For example, tomato (Lycopersicon esculentum Mill.) (ZALLER, 2007) and corn cultivars (genotypic differences) (LAZCANO et al., 2011) responded differently to vermicompost application, as observed in this study for some traits of cultivars AG 1051 and BR 106. On the other hand, Arancon et al. (2004b) found that the response of strawberry to vermicompost rate was affected by the location of the experiment. 
P. S. L. SILVA et al.

Table 3. Mean weight of green ears of corn cultivars as a response to the application of vermicompost rates, obtained from cattle manure ${ }^{1}$.

\begin{tabular}{|c|c|c|c|c|c|c|c|c|c|}
\hline \multirow{4}{*}{$\begin{array}{l}\text { Vermicompost } \\
\text { rates } \\
\left(\mathrm{Mg} \mathrm{ha}^{-1}\right)(\mathrm{x})\end{array}$} & \multicolumn{9}{|c|}{ Ear weight $\left(\mathrm{kg} \mathrm{ha}^{-1}\right)$} \\
\hline & \multicolumn{3}{|c|}{ Total } & \multicolumn{3}{|c|}{ Marketable unhusked } & \multicolumn{3}{|c|}{ Marketable husked } \\
\hline & \multicolumn{3}{|c|}{ Cultivars } & \multicolumn{3}{|c|}{ Cultivars } & \multicolumn{3}{|c|}{ Cultivars } \\
\hline & AG 1051 & BR 106 & Means & AG 1051 & BR 106 & Means & AG 1051 & BR 106 & Means \\
\hline 0 & 10409 & 9192 & 9801 & 10027 & 8926 & 9477 & 6008 & 4600 & 5304 \\
\hline 2 & 11682 & 11593 & 11638 & 11231 & 9013 & 10122 & 6508 & 6227 & 6368 \\
\hline 4 & 12791 & 12234 & 12513 & 12488 & 11363 & 11926 & 7759 & 6489 & 7124 \\
\hline 6 & 15092 & 12041 & 13567 & 15092 & 11382 & 13237 & 9035 & 6378 & 7707 \\
\hline 8 & 13318 & 11816 & 12567 & 13128 & 11286 & 12207 & 8180 & 6335 & 7258 \\
\hline 10 & 13716 & 12058 & 12887 & 13716 & 11462 & 12589 & 8283 & 6380 & 7332 \\
\hline Means & $12835 \mathrm{a}$ & $11489 \mathrm{~b}$ & - & $12614 \mathrm{a}$ & $10935 \mathrm{~b}$ & - & $7629 a$ & $6068 \mathrm{~b}$ & - \\
\hline \multicolumn{10}{|c|}{ Regression analysis for total weight of green ears (y) } \\
\hline Cultivars & \multicolumn{5}{|c|}{ Equations $^{1}$} & \multicolumn{2}{|c|}{$\mathrm{x}$ for $\mathrm{y} \max$} & $\mathrm{y} \max$ & $R^{2}$ \\
\hline AG 1051 & \multicolumn{5}{|c|}{$\mathrm{y}^{2}=104072000+23552900 \mathrm{x}-1538700 \mathrm{x}^{2}$} & \multicolumn{2}{|c|}{7.65} & 13936 & 0.82 \\
\hline BR 106 & \multicolumn{5}{|c|}{$y^{2}=89762900+19089500 x-1437100 x^{2}$} & \multicolumn{2}{|c|}{6.64} & 12376 & 0.87 \\
\hline Mean & \multicolumn{5}{|c|}{$\mathrm{y}=9888+949 \mathrm{x}-67 \mathrm{x}^{2}$} & \multicolumn{2}{|c|}{7.04} & 13229 & 0.93 \\
\hline \multicolumn{10}{|c|}{ Regression analysis for weight of marketable unhusked green ears (y) } \\
\hline Cultivars & \multicolumn{5}{|c|}{ Equations $^{1}$} & \multicolumn{2}{|c|}{$\mathrm{x}$ for $\mathrm{y} \max$} & $y \max$ & $R^{2}$ \\
\hline AG 1051 & \multicolumn{5}{|c|}{$\mathrm{y}^{2}=97348500+31260000 \mathrm{x}^{0.5}$} & \multicolumn{2}{|c|}{10.00} & 14007 & 0.73 \\
\hline BR 106 & \multicolumn{5}{|c|}{$\mathrm{y}=8711+942 \mathrm{x}^{0.5}$} & \multicolumn{2}{|c|}{10.00} & 11689 & 0.76 \\
\hline Mean & \multicolumn{5}{|c|}{$\mathrm{y}^{2}=84178100+18179700 \mathrm{x}-1085700 \mathrm{x}^{2}$} & \multicolumn{2}{|c|}{8.37} & 12660 & 0.87 \\
\hline \multicolumn{10}{|c|}{ Regression analysis for weight of marketable husked green ears (y) } \\
\hline Cultivars & \multicolumn{5}{|c|}{ Equations $^{1}$} & \multicolumn{2}{|c|}{$\mathrm{x}$ for $\mathrm{y} \max$} & $\mathrm{y} \max$ & $R^{2}$ \\
\hline $\mathrm{AG} 1051$ & \multicolumn{5}{|c|}{$y=6150+136 x^{2}-12 x^{3}$} & & .75 & 8877 & 0.87 \\
\hline BR 106 & $\mathrm{y}=4617-$ & $28 x+156$ & & & & & .69 & 6483 & 0.99 \\
\hline Mean & $\mathrm{y}=5311+$ & $627 x-44 x$ & & & & & .19 & 7568 & 0.97 \\
\hline CVplots, $\%$ & & 17.0 & & & 18.2 & & & 19.8 & \\
\hline CVsubplots, $\%$ & & 10.3 & & & 11.8 & & & 13.2 & \\
\hline
\end{tabular}

${ }^{1}$ For each trait, means followed by the same letter, in each row, do not differ from each other at 0.05 probability by Tukey's test. All parameters for all equations were significant at 0.05 probability by the $t$ test.

Cultivar AG 1051 responded better to vermicompost application than cultivar BR 106 (Tables 2, 3 and 4). In general, the maximum yields in cultivar AG 1051 were obtained with higher vermicompost doses than those obtained with cultivar BR 106. With regard to environmental factors, it was observed that the response to vermicompost applications was dependent upon the material used in vermicomposting (TEJADA; BENITEZ, 2011), soil type (MANTOVANI et al., 2003), location (ARANCON et al., 2004b), year soil tillage and fertilizers (PATIL; SHEELAVANTAR, 2006), among others factors.

Similarly to this study, other authors observed linear responses for some traits and quadratic responses for others under increased vermicompost rates (SOUZA et al., 2003). Moreover, as in this work, other authors (MANTOVANI et al., 2003) also verified that crops responded negatively to high vermicompost rates and positively to low application rates (Tables 2 to 4 ).

The fact that crop responses to vermicompost applications depend on several factors makes it difficult to explain their effects. Vermicompost may influence plant growth directly or indirectly, through different chemical, physical and biological mechanisms. For instance, vermicompost has a wide range of indirect effects on plant growth, such as the mitigation or suppression of plant diseases (LAZCANO; DOMÍNGUEZ, 2011). Cavender, Atiyeh and Knee (2003) propose that a positive influence of vermicompost on sorghum growth was due more to improved physical and chemical soil properties than to improved soil biological properties. Vermicompost applications increased total organic carbon, total N, P, K, Ca, Zn, and Mn contents, and decreased soil $\mathrm{pH}$ (AZARMI; GIGLOU; TALESHMIKAIL, 2008). Soil density and porosity also improved when vermicompost was added to the soil (AZARMI; GIGLOU; TALESHMIKAIL, 2008).

Other authors, however, attribute the positive responses of crops to vermicompost applications to improved soil biological characteristics (ARANCON et al., 2004b; TEJADA; BENITEZ, 2011). Two important contributions of vermicompost are increased microbial populations and activity, which are key factors in soil nutrient cycling rates, producing substances that influence growth; and increased plant resistance or tolerance to disease (ARANCON; EDWARDS; BIERMAN, 2006). Increased microbial populations with increasing vermicompost doses would be the factor responsible for higher crop growth and yield. Microorganisms can produce materials that may affect plant growth, such as substances that act as plant hormones or 
growth regulators. Microorganisms such as bacteria, fungi, actinomycetes and algae may produce plant growth regulators such as auxins, gibberellins, cytokinins, ethylene, and abscisic acid (ARANCON et al., 2004a). Increased amounts of humic materials would also be responsible for increases in crop growth and yield. Those humic substances occur naturally in rotted animal manure and in other organic materials, but vermicomposting can increase their amounts and production rates (ARANCON et al., 2004a). Positive effects of humic substances on several corn traits have been recently demonstrated (EYHERAGUIBEL; SILVESTRE; MORARD, 2008).

Table 4. Mean values for grain yield of corn cultivars, number of kernels ear ${ }^{-1}$, and 100-kernel weight as a response to the application of vermicompost doses, obtained from cattle manure ${ }^{1}$.

\begin{tabular}{|c|c|c|c|c|c|c|c|c|c|}
\hline \multirow{3}{*}{$\begin{array}{l}\text { Vermicompost } \\
\text { doses } \\
\left(\mathrm{Mg} \mathrm{ha}^{-1}\right)(\mathrm{x})\end{array}$} & \multicolumn{3}{|c|}{ Grain yield $\left(\mathrm{kg} \mathrm{ha}^{-1}\right)$} & \multicolumn{3}{|c|}{ Number of kernels ear ${ }^{-1}$} & \multicolumn{3}{|c|}{ 100-kernel weight $(\mathrm{g})$} \\
\hline & \multicolumn{3}{|c|}{ Cultivars } & \multicolumn{3}{|c|}{ Cultivars } & \multicolumn{3}{|c|}{ Cultivars } \\
\hline & AG 1051 & BR 106 & Means & AG 1051 & BR 106 & Means & AG 1051 & BR 106 & Means \\
\hline 0 & $4972 \mathrm{a}$ & $4829 \mathrm{a}$ & 4901 & 340 & 352 & 346 & 29.5 & 28.6 & 29.1 \\
\hline 2 & $5440 \mathrm{a}$ & $4889 \mathrm{a}$ & 5165 & 357 & 342 & 350 & 28.2 & 30.1 & 29.2 \\
\hline 4 & $5558 \mathrm{a}$ & $5120 \mathrm{a}$ & 5339 & 370 & 342 & 356 & 28.0 & 33.5 & 30.8 \\
\hline 6 & $6919 \mathrm{a}$ & $5416 \mathrm{~b}$ & 6168 & 419 & 367 & 393 & 32.8 & 31.6 & 32.2 \\
\hline 8 & $6936 \mathrm{a}$ & $5200 \mathrm{~b}$ & 6068 & 408 & 367 & 388 & 32.0 & 32.0 & 32.0 \\
\hline 10 & $7163 \mathrm{a}$ & $4789 \mathrm{~b}$ & 5976 & 414 & 323 & 369 & 32.8 & 30.6 & 31.7 \\
\hline Means & - & - & - & $385 \mathrm{a}$ & $349 \mathrm{~b}$ & - & $30.5 \mathrm{a}$ & $31.0 \mathrm{a}$ & 30.8 \\
\hline \multicolumn{10}{|c|}{ Regression analysis for grain yield (y) } \\
\hline Cultivars & \multicolumn{5}{|c|}{ Equations 1} & \multicolumn{2}{|c|}{$\mathrm{x}$ for $\mathrm{y} \max$} & $y \max$ & $R^{2}$ \\
\hline AG 1051 & \multicolumn{5}{|c|}{$y=4964+240 x$} & \multicolumn{2}{|c|}{10.00} & 7365 & 0.90 \\
\hline BR 106 & \multicolumn{5}{|c|}{$y=4802+37 x^{2}-3.7 x^{3}$} & \multicolumn{2}{|c|}{6.62} & 5342 & 0.95 \\
\hline Mean & \multicolumn{5}{|c|}{$y=4903+58 x^{2}-4.7 x^{3}$} & \multicolumn{2}{|c|}{8.14} & 6180 & 0.93 \\
\hline \multicolumn{10}{|c|}{ Regression analysis for number of kernels ear $^{-1}(\mathrm{y})$} \\
\hline Cultivars & \multicolumn{5}{|c|}{ Equations $^{1}$} & \multicolumn{2}{|c|}{$\mathrm{x}$ for $\mathrm{y} \max$} & $\mathrm{y} \max$ & $R^{2}$ \\
\hline AG 1051 & \multicolumn{5}{|c|}{$\mathrm{y}=344+8.2 \mathrm{x}$} & \multicolumn{2}{|c|}{10.00} & 425 & 0.84 \\
\hline BR 106 & \multicolumn{5}{|c|}{$y=349$} & \multicolumn{2}{|c|}{-} & - & - \\
\hline Mean & \multicolumn{5}{|c|}{$y=341.4+2.6 x^{2}-0.23 x^{3}$} & \multicolumn{2}{|c|}{7.49} & 389 & 0.88 \\
\hline \multicolumn{10}{|c|}{ Regression analysis for 100-kernel weight (y) } \\
\hline Cultivars & \multicolumn{5}{|c|}{ Equations $^{1}$} & \multicolumn{2}{|c|}{$\mathrm{x}$ for $\mathrm{y} \max$} & $\mathrm{y} \max$ & $R^{2}$ \\
\hline $\mathrm{AG} 1051$ & \multicolumn{5}{|c|}{$\mathrm{y}=30.5$} & \multicolumn{2}{|c|}{-} & - & - \\
\hline BR 106 & \multicolumn{5}{|c|}{$\mathrm{y}^{-1}=0.0352-0.0025 \mathrm{x}+0.0007 \mathrm{x}^{1.5}$} & & 47 & 32.6 & 0.78 \\
\hline Mean & $\mathrm{y}=28.97$ & $0.162 \mathrm{x}^{2}$ & $0.014 x^{3}$ & & & & 95 & 32.4 & 0.96 \\
\hline CVplots, $\%$ & & 17.8 & & & 14.3 & & & 8.2 & \\
\hline CVsubplots, \% & & 13.5 & & & 12.8 & & & 9.8 & \\
\hline
\end{tabular}

In this study, the application of vermicompost application may have contributed to improving soil biological, chemical (Table 2), and physical properties, including higher moisture retention. Even though the experiment was irrigated, the prevailing weather conditions during the study period, which included high temperatures and insolation and lack of rain, suggest that the retention of additional moisture in the soil may have been beneficial to corn. Baumhardt and Lascano (1996) reported that mean cumulative rainfall infiltration was lowest in bare soil and increased curvilinearly with increasing residue amounts.

The factors responsible for the negative responses of crops from a given vermicompost dose include high concentrations of soluble salts, toxicity for heavy metals (ARANCON et al., 2004a), and antagonistic effects of microorganisms that are present in the vermicompost (CAVENDER; ATIYEH; KNEE, 2003).

\section{CONCLUSIONS}

Vermicompost application increased total and marketable number and weight of green ears, both unhusked and husked, as well as grain yield.

Total number of green ears was higher in cultivar BR 106 than in cultivar AG 1051. The opposite occurred for total weight and marketable weight of green ears, both unhusked and husked, as well as for grain yield. However, in those last two traits the superiority of cultivar AG 1051 was dependent upon fertilizer rate.

\section{REFERENCES}

ALVAREZ, V. V. H. et al. Crescimento de plantas de milho pela adição de vermicomposto enriquecido ou não com fosfatos e com gesso. Revista Ceres, Viçosa, v. 51, n. 297, p. 635-647, 2004 
ARANCON, N. Q.; EDWARDS, C. A.; BIERMAN, $P$. Influences of vermicomposts on field strawberries: Part 2. Effects on soil microbiological and chemical properties. Bioresource Technology, Amsterdam, v. 97, n. 6 , p. 831-840, 2006.

ARANCON, N. Q. et al. Effects of vermicomposts from food waste on the growth and yields of greenhouse peppers. Bioresource Technology, Amsterdam, v. 93, n. 2, p. 139-144, 2004a.

ARANCON, N. Q.; GALVIS, P. A.; EDWARDS, C. A. Suppression of insect pest populations and damage to plants by vermicomposts. Bioresource Technology, Amsterdam, v. 96, n. 10, p. 1137-1142, 2005.

ARANCON, N. Q. et al. Influences of vermicomposts on field strawberries: 1. Effects on growth and yields. Bioresource Technology, Amsterdam, v. 93, n. 2, p. 145-153, 2004b.

AZARMI, R.; GIGLOU, M. T.; TALESHMIKAIL, R. D. Influence of vermicompost on soil chemical and physical properties in tomato (Lycopersicum esculentum) field. African Journal of Biotechnology, Lagos, v. 7, n. 14, p. 2397-2401, 2008.

BARTLETT, M. S. Some examples of statistical methods of research in agriculture and applied biology. Journal of Royal Statistical Society, London, v. 4, n. 2, p. 137-183, 1937.

BAUMHARDT, R. L.; LASCANO, R. J. Rain infiltration as affected by wheat residue amount and distribution in ridged tillage. Soil Science of the Society American Journal, Madison, v. 60, n. 6, p. 1908-1913, 1996.

BRITO, L. U. et al. Effect of pig litter composted on growth of maize (Zea mays) and havanan pepper (Capsicum chinense) plants. Research Journal of Biological Sciences, Lucknow, v. 4, n. 4, p. 514-518, 2009.

CARMO FILHO, F.; OLIVEIRA, O. F. Mossoró: um município do semi-árido nordestino. Mossoró: ESAM, 1989. 62 p. (Coleção Mossoroense, 672).

CAVENDER, N. D.; ATIYEH, R. M.; KNEE, M. Vermicompost stimulates mycorrhizal colonization of roots of Sorghum bicolor at the expense of plant growth. Pedobiologia, Leipzig, v. 47, n. 1, p. 85-89, 2003.

DINESH, R. et al. Short-term incorporation of organic manures and biofertilizers influences biochemical and microbial characteristics of soils under an annual crop [Turmerci (Curcuma longa
L.)]. Bioresource Technology, Amsterdam, v. 101, n. 12 , p. 4697-4702, 2010.

EMPRESA BRASILEIRA DE PESQUISA AGROPECUÁRIA - EMBRAPA. Centro Nacional de Pesquisa do Solo. Manual de análises químicas de solos, plantas e fertilizantes. Brasília, DF: EMBRAPA, 1999. 370 p.

EMPRESA BRASILEIRA DE PESQUISA AGROPECUÁRIA - EMBRAPA. Sistema brasileiro de classificação de solos. 2 . ed. Brasília, DF: Embrapa SPI, 2006. 412 p.

EYHERAGUIBEL, B.; SILVESTRE, J.; MORARD, P. Effects of humic substances derived from organic waste enhancement on the growth and mineral nutrition of maize. Bioresource Technology, Amsterdam, v. 99, n. 10, p. 4206-4212, 2008.

GUTIÉRREZ-MICELI, F. A. et al. Sheep manure vermicompost supplemented with a native diazotrophic bacteria and micorrhizas for maize cultivation. Bioresource Technology, Amsterdam, v. 99 , n. 15 , p. $7020-7026,2008$.

JANDEL. Jandel TBLCURVE. Table Curve 3.0. Curve fitting software. Corte Madera: Jandel Scientific, 1992. $280 \mathrm{p}$.

LAZCANO, C.; DOMÍNGUEZ, J. The use of vermicompost in sustainable agriculture: impact on plant growth and soil fertility. In: MIRANSARI, M. (Ed.). Soil nutrients. New York: Nova Science Publishers, 2011. chap. 10, p. 211-234.

LAZCANO, C. et al. Yield and fruit quality of four sweet corn hybrids (Zea mays) under conventional and integrated fertilization with vermicompost. Journal of the Science of Food and Agriculture, New York, v. 91, n. 7, p. 1244-1253, 2011.

MANLAY, R. J.; FELLER, C.; SWIFT, M. J. Historical evolution of soil organic matter concepts and their relationships with the fertility and sustainability of cropping systems. Agriculture, Ecosystems \& Environment, Amsterdam, v. 119, n. 3-4, p. 217-233, 2007

MANTOVANI, J. R. et al. Calagem e adubação com vermicomposto de lixo urbano na produção e nos teores de metais pesados em alface. Horticultura Brasileira, Brasília, v. 21, n. 3, p. 494-500, 2003.

MARIN, A. M. P. et al. Efeito da Gliricidia sepium sobre nutrientes do solo, microclima e produtividade do milho em sistema agroflorestal no Agreste Paraibano. Revista Brasileira de Ciência do Solo, Viçosa, v. 30, n. 3, p. 555-564, 2006. 
PATIL, S. L.; SHEELAVANTAR, M. N. Soil water conservation and yield of winter sorghum (Sorghum bicolor L. Moench) as influenced by tillage, organic materials and nitrogen fertilizer in semi-arid tropical India. Soil \& Tillage Research, Amsterdam, v. 89, n. 2, p. 246-257, 2006.

PIMENTEL-GOMES, F. Curso de estatística experimental. 15. ed. Piracicaba, SP: FEALQ, 2009. $415 \mathrm{p}$.

RIBEIRO JÚNIOR, J. I. Análises estatísticas no SAEG. Viçosa, MG: UFV, 2001. 301 p.

SILVA, C. J. et al. Crescimento e produção de rabanete cultivado com diferentes doses de húmus de minhoca e esterco bovino. Revista Ceres, Viçosa, v. 53, n. 305, p. 23-28, 2006.

SOUZA, C. A. S. et al. Crescimento de mudas de gravioleira (Annona muricata L.) em substrato com superfosfato simples e vermicomposto. Revista Brasileira de Fruticultura, Jaboticabal, v. 25, n. 3, p. 453-456, 2003.

SUJATHA, M. G. et al. Importance of integrated nutrient management practices in maize under rainfed condition. Karnataka Journal of Agricultural Science, Dharwar, v. 21, n. 3, p. 334-338, 2008.

TEJADA, M; BENITEZ, C. Organic amendment based on vermicompost and compost: differences on soil properties and maize yield. Waste Management Research, Kuala Lumpur, v. 29, n. 11, p. 1185-1196, 2011.

ZALLER, J. G. Vermicompost as a substitute for peat in potting media: effects on germination, biomass allocation, yields and fruit quality of three tomato varieties. Scientia Horticulturae, Amsterdam, v. 112, n. 2, p. 191-199, 2007. 